\title{
Influence of chemical composition on biochemical methane potential of fruit and vegetable waste
}

\author{
Thiago Edwiges ${ }^{\mathrm{a}, \mathrm{e}}$, Laercio Frare ${ }^{\mathrm{a}}$, Bruna Mayer ${ }^{\mathrm{a}}$, Leonardo Lins ${ }^{\mathrm{b}}$, Jin Mi Triolo ${ }^{\mathrm{c}}$, \\ Xavier Flotats ${ }^{\mathrm{d}}$, Mônica Sarolli Silva de Mendonça Costa ${ }^{\mathrm{e}}$
}

a Department of Biological and Environmental Sciences, Federal University of Technology - Parana, Avenida Brasil 4232, Medianeira, Brazil

b International Center on Renewable Energy - Biogas, Avenida Tancredo Neves 6731, Foz do Iguaçu, Brazil

c Institute of Chemical Engineering, Biotechnology and Environmental Technology, Faculty of Engineering, University of Southern Denmark, Campusvej 55, Odense M 5230, Denmark

d GIRO Joint Research Unit IRTA/UPC, Department of Agrifood Engineering and Biotechnology, Universitat Politècnica de Catalunya Barcelona TECH, Campus Mediterreni de la Tecnologia, Building D4, E-08860 Castelldefels, Spain

e Research Group on Water Resources and Environmental Sanitation, Western Parana State University, Agricultural Engineering Graduate Program, Rua Universitária, 2069 Jardim Universitário, 85.819-110 Cascavel, Paraná, Brazil

\begin{abstract}
This study investigates the influence of chemical composition on the biochemical methane potential (BMP) of twelve different batches of fruit and vegetable waste (FVW) with different compositions collected over one year. BMP ranged from 288 to $516 \mathrm{~L}_{\mathrm{N}}$ $\mathrm{CH}_{4} \mathrm{~kg} \mathrm{VS}^{-1}$, with significant statistical differences between means, which was explained by variations in the chemical composition over time. BMP was most strongly correlated to lipid content and high calorific values. Multiple linear regression was performed to develop statistical models to more rapidly predict methane potential. Models were analysed that considered chemical compounds and that considered only high calorific value as a single parameter. The best BMP prediction was obtained using the statistical model that included lipid, protein, cellulose, lignin, and high calorific value (HCV), with $\mathrm{R}^{2}$ of $92.5 \%$; lignin was negatively correlated to methane production. Because $\mathrm{HCV}$ and lipids are strongly correlated, and because $\mathrm{HCV}$ can be determined more rapidly than overall chemical composition, HCV may be useful for predicting BMP.
\end{abstract}

Keywords: anaerobic digestion; biodegradability; biogas; BMP model; lignocellulose. 
Edwiges, T., Mayer, B., Frare, L., Lins, L., Triolo, J.M., Flotats, X., Sarolli, M., (2017). Influence of chemical composition on biochemical methane potential of fruit and vegetable waste. Waste Management (accepted May 18th). DOI: https://doi.org/10.1016/i.wasman.2017.05.030

\section{INTRODUCTION}

Fruit and vegetable waste (FVW) is an important category of waste that is produced in large amounts in wholesale markets and through other activities around the world (Sitorus et al., 2013; Viturtia et al., 1995). Approximately 1,728 million tons of fruit and vegetables were produced worldwide in 2011; Brazil has a leading position in this market, as the third largest fruit producer in the world and the third largest vegetable producer in the Americas (FAO, 2014a).

According to the Food Wastage Footprint and Climate Change Report (FAO, $2014 b$ ), around $15 \%$ of fruit and $25 \%$ of vegetables are wasted at the bottom of the production chain. Traditionally, about $97 \%$ of Brazilian household and public waste, including FVW, enters landfills and dumping sites, while only $2 \%$ of waste is recycled and $1 \%$ is composted; there is no registered data about energy recovery (IPEA, 2011).

FVW is characterized by high moisture content and rich biodegradable organic compounds, typically with solid content under $10 \%$, and $85 \%$ corresponding to organic matter (Scano et al., 2014; Wang et al., 2014). These characteristics may contribute to negative issues in traditional solid waste disposal systems, such as greenhouse gas emissions and leachate discharge in landfills (Hartmann and Ahring, 2006). Along with these negative environmental impacts, the production of FVW increases market operating costs due to transport costs, sales losses, and disposal costs (Scano et al., 2014).

In contrast to this loss, anaerobic digestion (AD) can convert FVW into biogas, which can be used to produce energy while avoiding the aforementioned environmental issues (De Baere, 2006; Kafle et al., 2014). AD is a widely applied biochemical conversion process for the treatment of organic wastes such as manure, crop residues, and FVW (Apples et al., 2011). The scientific literature contains several studies on AD of FVW (Jiang et al., 2012; Lin et al., 2011;; Sitorus et al., 2013; Wang et al., 2014), but 
Edwiges, T., Mayer, B., Frare, L., Lins, L., Triolo, J.M., Flotats, X., Sarolli, M., (2017). Influence of chemical composition on biochemical methane potential of fruit and vegetable waste. Waste Management (accepted May 18th). DOI: https://doi.org/10.1016/i.wasman.2017.05.030

only a few studies have been carried out using FVW as the only substrate. Moreover, few studies report the influence of organic matter composition on biochemical methane potential (BMP) over time.

A consequence of the increasing implementation of $\mathrm{AD}$ is the need to determine the ultimate methane potential of substrates, as this is a key parameter for implementation of AD processes (Angelidaki et al., 2009). One way to determine the properties of a given substrate for AD is to perform BMP assays on the substrate as well as macromolecular composition analysis to provide a good characterization of the substrate's organic features (Cabbai et al., 2013; Holliger et al., 2016; Raposo et al., 2011).

Organic matter can be fractionated into easily biodegradable compounds including carbohydrates, lipids, and proteins, and poorly biodegradable compounds such as lignocellulosic biopolymers (Triolo et al., 2012). Although characteristics such as solid content of FVW show little variation, the quality of organic matter must also be investigated, as methane productivity depends not only on the amount of volatile solids, but also on the nature of the organic compounds (Buffiere et al., 2006).

Unfortunately, BMP testing is very time consuming, as it is based on microbial processes (Lesteur et al., 2010; Strömberg et al., 2015). However, there is a relationship between methane yield and the type of organic matter found in substrate. Some studies have successfully found this relationship by building mathematical regression models that compare the organic matter and the amount of methane produced (Buffiere et al., 2006; Cu et al., 2015; Dandikas et al., 2014). However, none of them has used FVW as a single substrate.

The objective of this study was to determine the BMP of FVW and the relationship between methane production and the macromolecular composition of FVW using twelve 
Edwiges, T., Mayer, B., Frare, L., Lins, L., Triolo, J.M., Flotats, X., Sarolli, M., (2017). Influence of chemical composition on biochemical methane potential of fruit and vegetable waste. Waste Management (accepted May 18th). DOI: https://doi.org/10.1016/j.wasman.2017.05.030

different FVW mixtures sampled monthly over the course of one year in Brazil. Moreover, a statistical model was generated to predict BMP.

\section{MATERIAL AND METHODS}

\subsection{Substrate and analytical methods}

Samples of FVW were collected monthly between September 2014 and August 2015 (12 in total) from a Municipal Central Supply (Foz do Iguaçu/Brazil) for determination of BMP. Samples consisted of stem, leaves, seeds and fruit bodies, which were homogenized immediately after collection by milling in an industrial blender (Polis LS-08); water was not added in order to maintain the original physical characteristics. Total solids (TS), volatile solids (VS) and $\mathrm{pH}$ were determined according to standard methods (APHA, 2005). To minimize the effect of sample aging and improve analytical precision, all samples were then dried at $60^{\circ} \mathrm{C}$, ground to a diameter smaller than $2 \mathrm{~mm}$, and refrigerated at $4{ }^{\circ} \mathrm{C}$ until use. The drying and milling process does not significantly affect the ultimate methane potential, but it can improve the precision of tests (Raju et al., 2011; Triolo et al., 2012; Triolo et al., 2014; Wahid et al., 2015).

Chemical composition and high calorific value $(\mathrm{HCV})$ were determined from the dried sample. To express the chemical composition as solids content, and to determine the solids conditions of BMP tests, TS and VS were also determined from the dried sample. Lipid (LP) content and total Kjeldahl nitrogen (TKN) content were determined according to tandard methods (APHA, 2005). Protein (PT) content was estimated by multiplying TKN by a factor of 6.25 (FAO, 2002), considering that ammonia nitrogen concentration is negligible.

Carbohydrates (CB) were estimated by the difference between 100 and the sum of the percentages of protein, lipid, lignin, water and ash (FAO, 2002). Neutral detergent fiber (NDF), acid detergent fiber (ADF) and acid detergent lignin (ADL) were measured 
Edwiges, T., Mayer, B., Frare, L., Lins, L., Triolo, J.M., Flotats, X., Sarolli, M., (2017). Influence of chemical composition on biochemical methane potential of fruit and vegetable waste. Waste Management (accepted May 18th). DOI: https://doi.org/10.1016/j.wasman.2017.05.030

to determine cellulose (CL), hemicellulose (HC), and lignin (LG) content according to Van Soest et al. (1991). Non-lignocellulosic carbohydrate (NLC) content was estimated by the difference between 100 and the sum of protein, lipid, water, ash, and lignocellulose (cellulose, hemicellulose, and lignin). A calorimeter pump was used to determine HCV (DIN 51900/00) of the dried samples.

\subsection{BMP assay}

The BMP was determined using a batch technique based on the guidelines proposed by VDI 4630 (2006). The system was composed of 39 glass reactors $(200 \mathrm{~mL}$ each) coupled to graduated eudiometer tubes $(300 \mathrm{~mL})$. For each treatment (month of collection), three reactors were incubated with inoculum and substrate; three reactors containing only inoculum were used as control, for a total of 39 batch reactors. All tests were performed at the same time.

The inoculum was a mixture of two digestates and one organic waste - effluent from a biogas plant processing swine manure, effluent from a biogas plant processing cattle manure and a raw cattle manure, respectively - obtained from the mesophilic demonstration units of the International Centre for Renewable Energy - Biogas located in western Parana/Brazil. The mixture ratio was 1:0.5:0.5 \% (wt/wt\%).

The inoculum was kept in a stainless steel reactor (working volume of $100 \mathrm{~L}$ ) under continuous stirring at $60 \mathrm{rpm}$ and the temperature was controlled at $37{ }^{\circ} \mathrm{C}$. The inoculum was maintained by weekly feeding with a mixture of substrates with an organic loading rate (OLR) of $0.5 \mathrm{VS} \mathrm{kg} \mathrm{m} \mathrm{m}^{-1}$ to keep it adapted and active. The feeding substrate was composed of powdered milk (25\%), soy protein (10\%), maize flour (20\%), dry grass (25\%), and vegetable oil (20\%). The inoculum feeding procedure is a strategy of the International Centre for Renewable Energy - Biogas to maintain it in anaerobic 
Edwiges, T., Mayer, B., Frare, L., Lins, L., Triolo, J.M., Flotats, X., Sarolli, M., (2017). Influence of chemical composition on biochemical methane potential of fruit and vegetable waste. Waste Management (accepted May 18th). DOI: https://doi.org/10.1016/j.wasman.2017.05.030

mesophilic condition and acclimatized to several substrate compositions over time, as the availability of mesophilic biogas plants in Brazil is limited.

Three additional glass reactors were used to study the biological activity of the inoculum in a parallel test, using microcrystalline cellulose as the reference sample (Sigma-Aldrich, $20 \mu \mathrm{m}$ diameter). After 10 days of batch AD, the biogas volume reached the minimum recommended by VDI 4630 (80\% of the theoretical production of biogas, $740-750 \mathrm{~mL}_{\mathrm{N}} \mathrm{g} \mathrm{VS}^{-1}$ ), validating the effectiveness of the inoculum used in the tests.

AD tests were performed with $1 \mathrm{~g}$ VS substrate and $200 \mathrm{~mL}$ inoculum. All masses were recorded and the gas production related to the inoculum was subtracted for each reactor. Solids content was kept below the recommendations provided by VDI 4630 with TS under $10 \%$, VS between $1.5 \%$ and $2.0 \%$, and inoculum to substrate ratio (ISR) greater than 2 to prevent inhibitions during the experiment. Nitrogen gas was used to purge the air contained in the reactors. The batch experiment was maintained in a water bath at a controlled temperature of $37^{\circ} \mathrm{C}$ for 32 days, at which point daily production represented less than $1 \%$ of the total accumulated produced gas. Digesters were agitated daily via manual shaking.

\subsection{Methane content}

The measured biogas was corrected to dried biogas at normal temperature and pressure conditions, and biogas yield was reported in normal litres per kilogram of volatile solids $\left(\mathrm{L}_{\mathrm{N}} \mathrm{kg} \mathrm{VS}^{-1}\right)$ from equations 1 and 2 at normal conditions:

$$
V_{0}=V \cdot \frac{\left(P_{L}-P_{W}\right) \cdot T_{0}}{P_{0} \cdot T} \quad \text { Eq. } 1
$$

where $V_{0}$ is biogas volume at normal conditions $(\mathrm{mL}) ; V$ is biogas volume recorded in the eudiometer $(\mathrm{mL}) ; P_{L}$ is atmospheric pressure at the time of registration 
Edwiges, T., Mayer, B., Frare, L., Lins, L., Triolo, J.M., Flotats, X., Sarolli, M., (2017). Influence of chemical composition on biochemical methane potential of fruit and vegetable waste. Waste Management (accepted May 18th). DOI: https://doi.org/10.1016/i.wasman.2017.05.030

(mbar); $P_{W}$ is vapor pressure of water (mbar); $T_{0}$ is normal temperature $(273 \mathrm{~K}) ; P_{0}$ is normal pressure (1013 mbar); and $T$ is temperature $(\mathrm{K})$.

According to Strömberg et al. (2014), water vapour leads to overestimation of biogas volume by $2 \%$ to $8 \%$ at normal temperature and pressure conditions. Thus, the vapour pressure $\left(P_{w}\right)$ was included in order to obtain accurate measurements of biogas volume. Water vapour pressure was calculated using Equation 2 (Strömberg et al., 2014), supposing that the gas is saturated:

$$
P_{W}=10^{8.962-\frac{1,730.63}{T-39.724}}
$$

where $P_{W}$ is vapor pressure (mbar); and $T$ is temperature $(\mathrm{K})$.

Methane content of the corrected biogas volume was determined via gas chromatography (Clarus 680, Perkin Elmer) with a thermal conductivity detector and packed Plot Q column with a length $30 \mathrm{~m}$ and internal diameter of $0.32 \mathrm{~mm}$. Helium was used as the carrier gas with a flow rate of $30 \mathrm{~mL} \mathrm{~min}^{-1}$.

\subsection{Experimental data analysis}

Non-linear regression (NLR) was performed to fit the BMP data using the logistic curve of cumulative methane production, assuming that the degradation of each sample follows a first-order decay and considering the biochemical processes to not be rate limiting, which was deemed reasonable as microorganism concentration was very high (Eq. 3). The Levenberg-Marquardt method was adopted with a confidence interval (CI) of $95 \%$ for every parameter.

$$
B_{(t)}=B_{0}\left(1-e^{k_{d i s} \cdot t}\right)
$$

Eq. 3

where $B_{(t)}$ is the cumulative methane yield at time $t$ (day), $B_{0}$ is the biochemical methane potential $\left(\mathrm{L}_{\mathrm{N}} \mathrm{CH}_{4} \mathrm{~kg} \mathrm{VS}^{-1}\right)$ and $k_{\text {dis }}$ is the overall constant of disintegration and 
Edwiges, T., Mayer, B., Frare, L., Lins, L., Triolo, J.M., Flotats, X., Sarolli, M., (2017). Influence of chemical composition on biochemical methane potential of fruit and vegetable waste. Waste Management (accepted May 18th). DOI: https://doi.org/10.1016/i.wasman.2017.05.030

hydrolysis $\left(\mathrm{d}^{-1}\right)$ (Vavilin et al., 2008). The methane production rate (MPR) was considered to be the maximum slope at time zero determined by taking the derivative of Equation 3, where $B_{0}$ and $K_{d i s}$ were the parameters to be estimated by non-linear regression:

$$
\operatorname{MPR}\left(\frac{L_{N} C H_{4}}{k g_{V S} d}\right)=B_{0} \cdot k_{\text {dis }} \quad \text { Eq. } 4
$$

In order to evaluate the biodegradability of FVW, the theoretical (stoichiometric) BMP (TBMP) was calculated (Triolo et al., 2011). Because lignin is anaerobically nondegradable, the TBMP was not used to estimate methane potential; rather, it was used to asses biodegradability of the substrate by calculating the relationship between BMP and TBMP. To calculate TBMP, empirical formulae for each organic component were protein $\left(\mathrm{C}_{5} \mathrm{H}_{7} \mathrm{O}_{2} \mathrm{~N}\right)$, lipid $\left(\mathrm{C}_{57} \mathrm{H}_{104} \mathrm{O}_{6}\right)$, lignin $\left(\mathrm{C}_{10} \mathrm{H}_{13} \mathrm{O}_{3}\right)$, and carbohydrates (non-lignocellulosic carbohydrates, cellulose, and hemicellulose $)\left(\mathrm{C}_{6} \mathrm{H}_{10} \mathrm{O}_{5}\right)$ :

$$
\begin{gathered}
T B M P\left(L \mathrm{CH}_{4} g V S^{-1}\right)=0.415\left(\mathrm{LCH}_{4} g V S_{C L^{-1}}\right)\left[\left(C L\left(g g^{-1} V S\right)+H C\left(g g^{-1} V S\right)+N L C\left(g g^{-1} V S\right)\right]+0.727(L\right. \\
\left.C_{4} g V S^{-1}\right) L G\left(g g^{-1} V S\right)+0.496\left(L C_{4} g V S_{P T^{-1}}\right)\left[\left(P T\left(g g^{-l} V S\right)+1.014\left(L_{C H} g V S_{L P}^{-1}\right)\left(L P \left(g g^{-}\right.\right.\right.\right.
\end{gathered}
$$

where 0.415 is the TBMP of carbohydrate, which includes non-lignocellulosic carbohydrates, cellulose, and hemicellulose, 0.727 is the TBMP of lignin, 0.496 is the TBMP of protein, and 1.014 is the TBMP of lipid (Triolo et al. 2011).

Statistical analysis was performed by using descriptive statistics data from the physical and chemical characterization and BMP, $K_{d i s}$, and MPR. Analysis of variance (ANOVA) was used to identify the existence of significant differences between the treatment means, and the Tukey test $(p<0.05)$ was performed in order to group BMP data. Before ANOVA, data normality was verified using the Shapiro-Wilk test $(p<0.05)$ 
Edwiges, T., Mayer, B., Frare, L., Lins, L., Triolo, J.M., Flotats, X., Sarolli, M., (2017). Influence of chemical composition on biochemical methane potential of fruit and vegetable waste. Waste Management (accepted May 18th). DOI: https://doi.org/10.1016/j.wasman.2017.05.030

(Lewis and Orav, 1989). Multiple regression analysis was performed to provide a statistical model for predicting BMP. The stepwise regression method was used to identify useful subsets of the predictors.

\section{RESULTS AND DISCUSSION}

\subsection{Substrate composition}

A total of 42 kinds of fruits and vegetables were tracked over a one-year period; 18 types of fruit and vegetable wastes were found each month on average, with $43 \%$ fruit and $57 \%$ vegetable (Figure 1). In the marketplace, the expensive and soft fruits and vegetables (e.g. grapes and strawberries) are stored separately from low-cost rigid fruits and vegetables (e.g. cassava and potato) to avoid damage, so the samples collected in this study were mostly low-priced or soft fruit and vegetables.

(Figure 1 near here)

Changes in the qualitative composition of FVW over time did not alter the homogeneity $(\mathrm{CV} \leq 10 \%)$ of parameters such as $\mathrm{pH}$, TS, VS and HCV (Table 1). This indicates that FVW is characterized by a standard acid level and high moisture and is rich in biodegradable compounds, regardless of the types of fruits and vegetables present in the mixture. Nevertheless, changes in qualitative composition affected the chemical composition ( $\mathrm{CV} \geq 20 \%$ )in terms of protein, lipid, cellulose, hemicellulose, lignin, and non-lignocellulosic carbohydrate.

(Table 1 near here)

The chemical composition of FVW averaged $73 \pm 9 \%$ vs carbohydrates, $16 \pm 5 \%$ vs protein and $4 \pm 6 \%$ vs lipid (Figure 2). May and December showed significantly higher lipid $(p<0.05)$, contributing to the highest variation among the analysed parameters $(\mathrm{CV}$ $=138 \%)$. This was due to the presence of lipid-rich fruits such as avocado, with average lipid of $26 \%$ vs, while typical usual fruit and vegetable lipid content reported in the 
Edwiges, T., Mayer, B., Frare, L., Lins, L., Triolo, J.M., Flotats, X., Sarolli, M., (2017). Influence of chemical composition on biochemical methane potential of fruit and vegetable waste. Waste Management (accepted May 18th). DOI: https://doi.org/10.1016/j.wasman.2017.05.030

literature range from $0.1 \% \mathrm{vs}$ to1.2\%vs (Cechi, 1999). $\mathrm{HCV}$ ranged from $14.8 \mathrm{MJ} \mathrm{kg}^{-1}$ to 21.2 $\mathrm{MJ} \mathrm{kg}^{-1}$ and showed good agreement with lipid content and BMP; HCV, lipid and BMP were highest in December. Nevertheless, variations of HCV were relatively lower than variations of lipid and BMP.

(Figure 2 near here)

FVW collected in all months presented high non-lignocellulosic carbohydrate content (59\% of total carbohydrates), except for May and June, which presented high lignocellulose content $(p<0.001)$. FVW collected in those months contained fruit and vegetables with high fiber content such as garden egg, broccoli, persimmon fruit and melon.

\subsection{Batch anaerobic digestion test}

The ratio of inoculum to substrate (ISR) in all reactors varied from 3:1 to 4:1, and the $\mathrm{pH}$ at the beginning and at the end of the tests ranged from 7.3 to 7.7 (Table 2). Low $\mathrm{pH}$ variation was found among reactors, indicating that no acidification had occurred, due to the relatively high concentration of inoculum.

(Table 2 near here)

The fitted logistic curve (Equation 3) obtained via non-linear regression (Figure 3) was used to express BMP results with estimated confidence intervals. Based on the non-linear regression of the anaerobic batch experiments, the average BMP was $377 \pm 67$ $\mathrm{L}_{\mathrm{N}} \mathrm{CH}_{4} \mathrm{~kg} \mathrm{VS}^{-1}$. This is similar to the average BMP obtained by Jiang et al. (2012) who evaluated BMP on batch tests of FVW composed of $94 \%$ beans and corn $\left(352 \mathrm{LN} \mathrm{CH}_{4}\right.$ $\mathrm{kgVS}^{-1}$ ) and Lopez et al. (2016), who evaluated BMP of restaurant FVW composed mostly of raw vegetables $\left(388 \pm 53 \mathrm{~L}_{\mathrm{N}} \mathrm{CH}_{4} \mathrm{~kg} \mathrm{VS}^{-1}\right)$. Lin et al., (2011) found a lower BMP using a mixture of fruit (apple, banana, pear, and watermelon) and vegetable waste (cabbage, carrot and lettuce) produced over one year $\left(300 \mathrm{~L}_{\mathrm{N}} \mathrm{CH}_{4} \mathrm{~kg} \mathrm{VS}^{-1}\right)$, indicating 
Edwiges, T., Mayer, B., Frare, L., Lins, L., Triolo, J.M., Flotats, X., Sarolli, M., (2017). Influence of chemical composition on biochemical methane potential of fruit and vegetable waste. Waste Management (accepted May 18th). DOI: https://doi.org/10.1016/i.wasman.2017.05.030

higher protein content in that mixture. In addition, Scano et al. (2014) performed a fullscale reactor test with an OLR of $2.5 \mathrm{~kg} \mathrm{VS} \mathrm{m}^{-3} \mathrm{~d}^{-1}$ and obtained similar BMP values (430 $\mathrm{L}_{\mathrm{N}} \mathrm{CH}_{4} \mathrm{~kg} \mathrm{VS}^{-1}$ ) using different compositions of FVW collected over the course of one year.

The hydrolysis constant $\left(\mathrm{K} \mathrm{day}^{-1}\right)$ of FVW was fairly high (ranging from 0.39 day $^{-1}$ to 0.66 day $^{-1}$ ), highlighting that most of the degradable organic compounds are hydrolysed within the first week of anaerobic digestion. This rapid degradation is also clearly seen in Figure 3. Compared to $\mathrm{K}\left(\mathrm{day}^{-1}\right)$ of other biomasses, Pham et al. (2013) reported much slower degradation (pig manure and cattle manure), with hydrolysis constants of pig manure and cattle manure of $0.149 \mathrm{day}^{-1}$ and $0.106 \mathrm{day}^{-1}$, respectively.

Li et al. (2013) also found slower degradation of corn stove $\left(0.197 \mathrm{day}^{-1}\right)$. The very rapid degradation of VFW is in good agreement with its easily degradable organic composition, including particularly low lignocellulose content. These results highlight the very rapid biogas production, which requires shorter retention time in contrast to typical agricultural residues (e.g., cereal straw), which require long retention time at the biogas plant for sufficient methane production.

(Figure 3 near here)

Biogas production stabilized (daily production of less than $1 \%$ of the total accumulated gas) within 16 days of incubation for all substrates, with an average stabilization time of 12 days. Cabbai et al. (2013) and Jiang et al. (2012) reported stabilization times of about 10 days, indicating a faster conversion rate of organic matter into biogas. Three days from the beginning of incubation, The May and December FVW showed increased daily biogas production compared to the average values. This can be explained by the high lipid content in these substrates, which requires more time for hydrolysis. 
Edwiges, T., Mayer, B., Frare, L., Lins, L., Triolo, J.M., Flotats, X., Sarolli, M., (2017). Influence of chemical composition on biochemical methane potential of fruit and vegetable waste. Waste Management (accepted May 18th). DOI: https://doi.org/10.1016/i.wasman.2017.05.030

The biodegradability estimated by the relationship between BMP and TBMP for all months ranged from $63 \%$ to $98 \%$, with an average value of $79 \%$, which is considerably higher than the value obtained for other waste biomasses, i.e. animal manure and sludge. Biodegradability of animal manure was reported as $29 \%$ to $93 \%$ (Triolo et al. 2011), which is fairly low in comparison to FVW. While non-edible organic waste or agricultural lignocellulosic residues are perceived as typical recalcitrant biomasses with low biodegradability, this result highlights the potential of integrating fruit and vegetable waste into biogas production due to its fairly high BMP and biodegradability.

Lin et al. (2011) reported FVW biodegradability of 59\% in a mixture with high protein content. In the present study, samples with high lignocellulose content, such as February, June, July and October, showed relatively lower biodegradability. Nevertheless, all the FVW samples in this study were quite easily decomposed compared to other lignocellulosic biomasses, such as straw, maize, and miscanthus. The high biodegradability of FVW, which is due to its organic composition, is not similar to biomasses rich in lignocellulose; rather, it is similar to energy crops with abundant nonlignocellulosic carbohydrates and low amounts of lignocellulose (non-lignocellulose carbohydrate $47 \%$ of VS on average).

\subsection{Correlation between methane production and chemical composition}

ANOVA indicated a significant difference $(p<0.05)$ between the means of the BMP values of FVW collected over one year, which can be explained by variations in the chemical composition over time. This variation was investigated via correlation matrix (Table 3), showing the correlation coefficient and related statistical significance ( $p$ value).

(Table 3 near here) 
Edwiges, T., Mayer, B., Frare, L., Lins, L., Triolo, J.M., Flotats, X., Sarolli, M., (2017). Influence of chemical composition on biochemical methane potential of fruit and vegetable waste. Waste Management (accepted May 18th). DOI: https://doi.org/10.1016/i.wasman.2017.05.030

As expected, a positive correlation was found between BMP and lipid content, aslipids exhibit much higher biogas potential than carbohydrates and proteins, confirming the fact that the presence of lipid-rich fruits in a mixture of FVW has the strongest effect on methane potential. These results are in accordance with the high monthly variability of lipid content ranging from $1.4 \%$ to $22.3 \%$, which was primarily due to the presence of lipid-dense avocado in May and December. Dandikas et al. (2014) reported lignin as the parameter that best described methane yield from energy crops, with its content below 10\%. Cu et al. (2015) reported that lipids, proteins, cellulose, and lignin are the best predictors of BMP for combined animal and plant biomass, with lipid able to explain most of the variation $(59.9 \%)$.

The BMP's for May and December, which contained the highest levels of lipids, were statistically different $(p<0.05)$. Although lipid content in December was $114 \%$ higher than that in May, its December's lignocellulose content was also 60\% lower. Lignocellulose plays a less important role in BMP than lignocellulosic agricultural residues. Recent studies have reported that lignin is a strong predictor of organic waste and agricultural residues (Dandikas et al. 2015; Triolo et al. 2011), which mostly contain lignocelluloses. However, simple regression tests showed no significant correlation between lignocelluloses (hemicellulose, cellulose and lignin) and BMP $(\mathrm{p}<0.05)$ for the FVW in this study, nor was the level of correlation between them clear. This could be because the variation in lignocellulose content was not large enough to find a fine correlation, in contrast to lipid content, varied strongly depending on time.

HCV was moderately correlated with BMP and MPR, with high calorific values indicating expected high methane potential. This can be explained by the strong correlation between $\mathrm{HCV}$ and lipids. Regarding the time to characterize substrate 
Edwiges, T., Mayer, B., Frare, L., Lins, L., Triolo, J.M., Flotats, X., Sarolli, M., (2017). Influence of chemical composition on biochemical methane potential of fruit and vegetable waste. Waste Management (accepted May 18th). DOI: https://doi.org/10.1016/j.wasman.2017.05.030

parameters, $\mathrm{HCV}$, which can be obtained much more rapidly, may be useful for preliminary investigations.

\subsection{Multiple linear regression analysis}

We attempted to build simple regression and multiple regression models to predict BMP of FVW by applying high calorific value and various chemical components as either single or multiple variables (Table 4). A stepwise regression test was first conducted using the significantly correlated parameters (e.g HCV and lipids), and then we included additional parameters to test for improvements in model precision and correlation between measured and predicted values.

(Table 4 near here)

As lignin is non-degradable under anaerobic conditions (Triolo et al. 2011), lignin shows to be inversely correlated to BMP, which was also observed by Triolo et al. (2011) and Dandikas et al. (2014) using energy crops and $\mathrm{Cu}$ et al. (2015) using plant residues and animal manure. Although the correlation between measured and predicted BMP using only lignin in this study is quite low $\left(R^{2}=0.023\right)$, due perhaps to the very low concentration of lignin in all the samples, the model precision estimated by standard error is fairly fine. Moreover, the intercept (BMP $\mathrm{L}_{\mathrm{N}} \mathrm{CH}_{4} \mathrm{~kg}_{\mathrm{VS}}{ }^{-1}=402-3.85 \mathrm{LG} \% \mathrm{vs}$ ) was similar to that reported in previous studies (BMP $\mathrm{L} \mathrm{CH}_{4} \mathrm{kgVs}^{-1}=395-2.00 \mathrm{LG} \% \mathrm{vs}$, Dandikas et al. 2014; BMP L CH $4 \mathrm{kgVs}^{-1}=422-1.675$ LG \%vs, Triolo et al. (2011.)

Thus, using the average lignin content found in this study (3.5\%), the BMP obtained by these two models was very similar, with a difference of about $1 \%$ between them, confirming that for FVW with lignin content under $10 \%$, the models provide comparable results. Nevertheless, in the present study, lignin was not a key organic component in explaining the variation of BMP within FVW from different months; this may be due to its relatively low content and low variation. 
Edwiges, T., Mayer, B., Frare, L., Lins, L., Triolo, J.M., Flotats, X., Sarolli, M., (2017). Influence of chemical composition on biochemical methane potential of fruit and vegetable waste. Waste Management (accepted May 18th). DOI: https://doi.org/10.1016/i.wasman.2017.05.030

Models 1 and 2 showed very similar statistical metrics, indicating that high calorific value could be a useful alternative to chemical composition for predicting BMP, as determination of $\mathrm{HCV}$ requires less time. Furthermore, the data illustrated in Figure 4a indicate the residuals of Model 1 were unsystematically distributed, thus suggesting a good ability to account for variability in the data.

(Figure 4 around here)

For models using a single substrate, using lipid content results in the best model (Model 3), with the lowest model error compared to Model 1.

(Figure 5 near here)

When multiple variables were combined to predict BMP (models 4 to 7 ), the statistical metrics showed subsequently improvement, indicating the relative importance of various components in obtaining models with the best fit. In addition, $R^{2}$ improves from 0.891 to 0.925 when $\mathrm{HCV}$ is included in the multiple regression (Model 7). The residuals versus the predicted plot for this model are presented in Figure $4 \mathrm{~b}$ and show unsystematic distribution. Moreover, as seen in Figure 5, this model shows a reduced standard error (SE of 24.9), and the obtained trend line is very close to the best fit when $y=x$.

\section{CONCLUSIONS}

The qualitative composition of FVW found in the fruit market changes over time based on strength and market value. The variables $\mathrm{pH}$, TS, VS, and HCV show little variation, but the chemical composition in terms of carbohydrates, proteins and lipids is affected, with a coefficient of variation above $20 \%$. The average BMP of FVW is $377 \pm$ $67 \mathrm{~L}_{\mathrm{N}} \mathrm{CH}_{4} \mathrm{~kg}_{\mathrm{VS}}^{-1}$ with $79 \%$ biodegradability, which correlates well to lipid and HCV. The best BMP predictions were obtained using the statistical model that included lipid, protein, cellulose, lignin, and $\mathrm{HCV}$, with $\mathrm{R}^{2}$ of $92.5 \%$; lignin is negatively correlated to 
Edwiges, T., Mayer, B., Frare, L., Lins, L., Triolo, J.M., Flotats, X., Sarolli, M., (2017). Influence of chemical composition on biochemical methane potential of fruit and vegetable waste. Waste Management (accepted May 18th). DOI: https://doi.org/10.1016/i.wasman.2017.05.030

methane production. Because HCV and lipids are strongly correlated, and because HCV can be determined more rapidly than overall chemical composition, HCV may be useful for predicting BMP.

\section{ACKNOWLEDGMENT}

We thank the International Centre for Renewable Energy - Biogas (Foz do Iguaçu/Brazil) for technical support and instrumental cooperation in this research.

\section{REFERENCES}

APHA, 2005. Standard methods for the examination of water and wastewater, $21^{\text {st }} \mathrm{ed}$. American Public Health Association, DC.

Angelidaki, I., Alves, M., Bolzonella, D., Borzacconi, L, Campos, J.L., Guwy, A. J., Kalyuzhnyi, S., Jenicek, P., Van Lier J.B. 2009. Defining the biomethane potential (BMP) of solid organic wastes and energy crops: a proposed protocol for batch assays. Water Science \& Technology, 59, 927-934.

Appels, L., Lauwersa, J., Degrèvea, J., Helsen, L., Lievens, B., Willems, C., Impe, J.V., Dewil, R. 2011. Anaerobic digestion in global bio-energy production: potential and research challenges. Renewable and Sustainable Energy Reviews, 12, 4295-4301.

Buffiere, P., Loisel, D., Bernet, N., Delgenes, J.P. 2006. Towards new indicators for the prediction of solid waste anaerobic digestion properties. Water Science \& Technology, 53, 233-241.

Cabbai, V., Ballico, M., Aneggi, E., Goi, D. 2013. BMP tests of source selected OFMSW to evaluate anaerobic codigestion with sewage sludge. Waste Management, 33, 16261632.

Cecchi. H.M. 1999. Fundamentos teóricos e práticos em análise de alimentos. Editora da Unicamp: Campinas, Brasil. 
Edwiges, T., Mayer, B., Frare, L., Lins, L., Triolo, J.M., Flotats, X., Sarolli, M., (2017). Influence of chemical composition on biochemical methane potential of fruit and vegetable waste. Waste Management (accepted May 18th). DOI: https://doi.org/10.1016/i.wasman.2017.05.030

Cu, T.T.T., Nguyen, T.X., Triolo, J.M., Pedersen, L., Le, V.D., Le, P.D., Sommer, S.G. 2015. Biogas production from Vietnamese animal manure, plant residues and organic waste: influence of biomass composition on methane yield. Asian-Australasian Journal of Animal Sciences, 28, 280-289.

Dandikas, V., Heuwinkel, H., Lichti, F., Drewes, J.E., Kochc, K. 2014. Correlation between biogas yield and chemical composition of energy crops. Bioresource Technology, 174, 316-320.

De Baere, L. 2006. Will anaerobic digestion of solid waste survive in the future? Water Science \& Technology, 53, 187-194.

FAO. Food and Agriculture Organization of the United Nations. 2002. Food and nutrition paper 77: food energy (methods of analysis and conversion factors).

FAO. Food and Agriculture Organization of the United Nations. 2014a. FAO statistical yearbook 2014: Latin America and the Caribbean food and agriculture.

FAO. Food and Agriculture Organization of the United Nations. 2014b. Food wastage footprint: fool cost-accounting.

Hartmann, H., Ahring, B.K. 2006. Strategies for the anaerobic digestion of the organic fraction of municipal solid waste: An overview. Water Science \& Technology, 53, 722.

Holliger, C., Alves, M., Andrade, D., Angelidaki, I., Astals, S., Baier, U., Bougrier, C., Buffière, P., Carbella, M., De Wilde, V. 2016. Towards a standardization of biomethane potential tests. Water Science \& Technology, 74, 2515-2522.

IPEA. Instituto de Pesquisa Econômica Aplicada. 2011. Caderno diagnóstico - resíduos sólidos urbanos. http://www.cnrh.gov.br/projetos/pnrs/documentos/cadernos/0.pdf (accessed 10.10.16). 
Edwiges, T., Mayer, B., Frare, L., Lins, L., Triolo, J.M., Flotats, X., Sarolli, M., (2017). Influence of chemical composition on biochemical methane potential of fruit and vegetable waste. Waste Management (accepted May 18th). DOI: https://doi.org/10.1016/i.wasman.2017.05.030

Jiang, Y., Heaven, S. 2012. Strategies for stable anaerobic digestion of vegetable waste. Renewable Energy, 44, .206-214.

Kafle, G.K., Bhattarai, S., Kim, S.H., Chen, L. 2014. Effect of feed to microbe ratios on anaerobic digestion of Chinese cabbage waste under mesophilic and thermophilic conditions: biogas potential and kinetic study. Journal of Environmental Management, 133, 293-301.

Lesteur, M., Bellon-Maurel, V., Gonzalez, C., Latrille, E., Roger, J.M., Junqua, G., Steyer, J.P. 2010. Alternative methods for determining anaerobic biodegradability: A review. Process Biochemestry, 45, 431-444.

Li, Y., Zhang, R., Chen, C., Liu, G., He, Y., Liu, X. 2013. Biogas production from codigestion of corn stover and chicken manure under anaerobic wet, hemi-solid, and solid state conditions. Bioresource technology, 149, 406-412.

Lin, J., Zuo, J., Gan, L., Li, P., Liu, F., Wang, K., Chen, L., Gan. H. 2011. Effects of mixture ratio on anaerobic co-digestion with fruit and vegetable waste and food waste of China. Journal of Environmental Sciences, 23, 1403-1408.

Lewis, P.A.W., Orav, E.J. 1989. Simulation methodology for statisticians, operations analysts, and engineers. Chapman and Hall, London.

Lopez, V. M., De la Cruz, F. and M. A. Barlaz. 2016. Chemical Composition and Methane Potential of Commercial Food Wastes. Waste Management, 56, 477-90.

Pham, C.H., Triolo, J.M., Cu, T.T.T., Pedersen, L., Sommer, S.G. 2013. Validation and Recommendation of Methods to Measure Biogas Production Potential of Animal Manure. Asian-Australasian Journal of Animal Sciences, 26, 864-873.

Raju, C.S., Ward, A.J., Nielsen, L., Møller, H.B., 2011. Comparison of near infra-red spectroscopy, neutral detergent fibre assay and in-vitro organic matter digestibility 
Edwiges, T., Mayer, B., Frare, L., Lins, L., Triolo, J.M., Flotats, X., Sarolli, M., (2017). Influence of chemical composition on biochemical methane potential of fruit and vegetable waste. Waste Management (accepted May 18th). DOI: https://doi.org/10.1016/i.wasman.2017.05.030

assay for rapid determination of the biochemical methane potential of meadow grasses. Bioresource Technology, 102, 7835-7839.

Raposo, F., De La Rubia, M.A., Fernández-Cegrí, V., Borja, R. 2011. Anaerobic digestion of solid organic substrates in batch mode: An overview relating to methane yields and experimental procedures. Renewable and Sustainable Energy Reviews, 16, 861-877.

Scano, E.A., Asquer, C., Pistis, A., Ortu, L., Demontis, V., Cocco, D. 2014. Biogas from anaerobic digestion of fruit and vegetable wastes: Experimental results on pilot-scale and preliminary performance evaluation of a full-scale power plant. Energy Conversion and Management, 77, 22-30.

Sitorus, B., Sukandar, Panjaitanc, S.D. 2013. Biogas recovery from anaerobic digestion process of mixed fruit and vegetable wastes, Energy Procedia, 32, 176-182.

Strömberg. S., Nistor. M., Liu. J. 2014. Towards eliminating systematic errors caused by the experimental conditions in biochemical methane potential (BMP) tests. Waste Management, 34, 1939-1948.

Strömberg, S., Nistor, M., Liu, J. 2015. Early prediction of biochemical methane potential through statistical and kinetic modelling of initial gas production. Bioresource Technology, 176, 233-241.

Triolo, J.M., Sommer, S.G., Møller, H.B., Weisbjerg, M.R., Jian, X.Y. 2011. A new algorithm to characterize biodegradability of biomass during anaerobic digestion: Influence of lignin concentration on methane production potential. Bioresource Technology, 102, 9395-9402.

Triolo, J.M., Pedersen, L., Qu, H., Sommer, S.G. 2012. Biochemical methane potential and anaerobic biodegradability of non-herbaceous and herbaceous phytomass in biogas production. Bioresource Technology, 125, 226-232. 
Edwiges, T., Mayer, B., Frare, L., Lins, L., Triolo, J.M., Flotats, X., Sarolli, M., (2017). Influence of chemical composition on biochemical methane potential of fruit and vegetable waste. Waste Management (accepted May 18th). DOI: https://doi.org/10.1016/i.wasman.2017.05.030

Triolo, J.M., Ward, A.J., Pedersen, L., Løkke, M.M, Qu, H., Sommer, S. 2014. Near Infrared Reflectance Spectroscopy (NIRS) for rapid determination of biochemical methane potential of plant biomass. Applied Energy, 116, 52-57.

Van Soest, P.J., Robertson, J.B., Lewis, B.A.1991. Methods for dietary fiber, neutral detergent fiber, and nonstarch polysaccharides in relation to animal nutrition. Journal of Dairy Science, 74, 3583-3597.

Vavilin, V.A., Fernández, B., Palatsi, J., Flotats, X. 2008. Hydrolysis kinetics in anaerobic degradation of particulate organic matter: An overview. Waste Management, 28, 936-951.

VDI 4630, 2006. Fermentation of organic materials: characterization of the substrate, sampling, collection of material data, fermentation tests. In: Verein Deutscher Ingenieure, Berlin, Germany.

DIN 51900-1, 2000. Determining the gross calorific value of solid and liquid fuels using the bomb calorimeter, and calculation of net calorific value. In: Deutsches Institut für Normung, Berlin, Germany.

Viturtia, M.A., Mata-Alvarez, J., Cecchi, F. 1995. Two-phase continuous anaerobic digestion of fruit and vegetable wastes. Resources, Conservation and Recycling, 13, $257-267$.

Wahid, R., Ward, A. J., Møller, H. B., Søegaard, K., Eriksen, J. 2015. Biogas potential from forbs and grass-clover mixture with the application of near infrared spectroscopy. Bioresource Technology, 198, 124-132.

Wang, L., Shen, F., Yuan, H., Zoua, D., Liu, Y., Zhu, B., Li, X. 2014. Anaerobic codigestion of kitchen waste and fruit/vegetable waste: Lab-scale and pilot-scale studies. Waste Management, 34, 2627-2633. 


\section{FIGURE CAPTIONS}

- Figure 1. Qualitative composition of fruit and vegetable waste for each month (darkened squares indicate the month in which the type of fruit or vegetable waste was found).

- Figure 2. Distribution of proteins, lipids and carbohydrates (\% of volatile solids) over time.

- Figure 3. Example of fitted line plot with $95 \%$ confidence interval (C.I.) for months 1 (a), 5 (b), 10 (c), and 12 (d).

- Figure 4. Residuals versus predicted biochemical methane potential (BMP) plot using only HCV (a) and protein; lipid; cellulose; lignin and HCV (b).

- $\quad$ Figure 5. Measured versus predicted BMP using Model $7(\mathrm{BMP}=-73+5.85 \mathrm{PT}+$ 6.62 LP + 9.91 CL - 32.0 LG + 22.0 HCV) Dotted line denotes the obtained linear trend and the solid line is the best fit $(\mathrm{y}=\mathrm{x})$; SE: standard error: HCV: high calorific value; LP: lipid: PT: protein; Cl: cellulose; LG: lignin; HCV: high calorific value; $\mathrm{BMP}$ is expressed in $\mathrm{L}_{\mathrm{N}} \mathrm{CH}_{4} \mathrm{~kg} \mathrm{VS}{ }^{-1}$ 
Edwiges, T., Mayer, B., Frare, L., Lins, L., Triolo, J.M., Flotats, X., Sarolli, M., (2017). Influence of chemical composition on biochemical methane potential of fruit and vegetable waste. Waste Management (accepted May 18th). DOI: https://doi.org/10.1016/j.wasman.2017.05.030

\begin{tabular}{|c|c|c|c|c|c|c|c|c|c|c|c|c|}
\hline \multirow{2}{*}{ Type } & \multicolumn{12}{|c|}{ Month } \\
\hline & 1 & 2 & 3 & 4 & 5 & 6 & 7 & 8 & 9 & 10 & 11 & 12 \\
\hline \multicolumn{13}{|l|}{ Cassava } \\
\hline \multicolumn{13}{|l|}{ Chili } \\
\hline \multicolumn{13}{|l|}{ Avocado } \\
\hline \multicolumn{13}{|l|}{ Potato } \\
\hline \multicolumn{13}{|l|}{ Guava } \\
\hline \multicolumn{13}{|c|}{ Garden egg } \\
\hline \multicolumn{13}{|l|}{ Peach } \\
\hline \multicolumn{13}{|l|}{ Rucola } \\
\hline \multicolumn{13}{|c|}{ Watercress } \\
\hline \multicolumn{13}{|l|}{ Beet } \\
\hline \multicolumn{13}{|l|}{ Broccoli } \\
\hline \multicolumn{13}{|c|}{ Persimmon fruit } \\
\hline \multicolumn{13}{|c|}{ Cauliflower } \\
\hline \multicolumn{13}{|c|}{ Strawberry } \\
\hline \multicolumn{13}{|l|}{ Okra } \\
\hline \multicolumn{13}{|l|}{ Grape } \\
\hline \multicolumn{13}{|c|}{ String beans } \\
\hline \multicolumn{13}{|c|}{ Napa cabbage } \\
\hline \multicolumn{13}{|l|}{ Lettuce } \\
\hline \multicolumn{13}{|l|}{ Apple } \\
\hline Melon & & & & & & & & & & & & \\
\hline
\end{tabular}

\begin{tabular}{|c|c|c|c|c|c|c|c|c|c|c|c|c|}
\hline \multirow{2}{*}{ Type } & \multicolumn{12}{|c|}{ Month } \\
\hline & 1 & 2 & 3 & 4 & 5 & 6 & 7 & 8 & 9 & 10 & 11 & 12 \\
\hline \multicolumn{13}{|l|}{ Banana } \\
\hline \multicolumn{13}{|l|}{ Sweet potato } \\
\hline \multicolumn{13}{|l|}{ Mango } \\
\hline \multicolumn{13}{|l|}{ Passion fruit } \\
\hline \multicolumn{13}{|l|}{ Pineapple } \\
\hline \multicolumn{13}{|l|}{ Pumpkin } \\
\hline \multicolumn{13}{|l|}{ Plum } \\
\hline \multicolumn{13}{|l|}{ Chayote } \\
\hline \multicolumn{13}{|l|}{ Carrot } \\
\hline \multicolumn{13}{|l|}{ Papaya } \\
\hline \multicolumn{13}{|l|}{ Watermelon } \\
\hline \multicolumn{13}{|l|}{ Cucumber } \\
\hline \multicolumn{13}{|l|}{ Pepper } \\
\hline \multicolumn{13}{|l|}{ Zucchinni } \\
\hline \multicolumn{13}{|l|}{ Eggplant } \\
\hline \multicolumn{13}{|l|}{ Onion } \\
\hline \multicolumn{13}{|l|}{ Lemon } \\
\hline \multicolumn{13}{|l|}{ Cabbage } \\
\hline \multicolumn{13}{|c|}{ Collard greens } \\
\hline \multicolumn{13}{|l|}{ Orange } \\
\hline Tomato & & & & & & & & & & & & \\
\hline
\end{tabular}

Figure 1. 
Edwiges, T., Mayer, B., Frare, L., Lins, L., Triolo, J.M., Flotats, X., Sarolli, M., (2017). Influence of chemical composition on biochemical methane potential of fruit and vegetable waste. Waste Management (accepted May 18th). DOI: https://doi.org/10.1016/j.wasman.2017.05.030

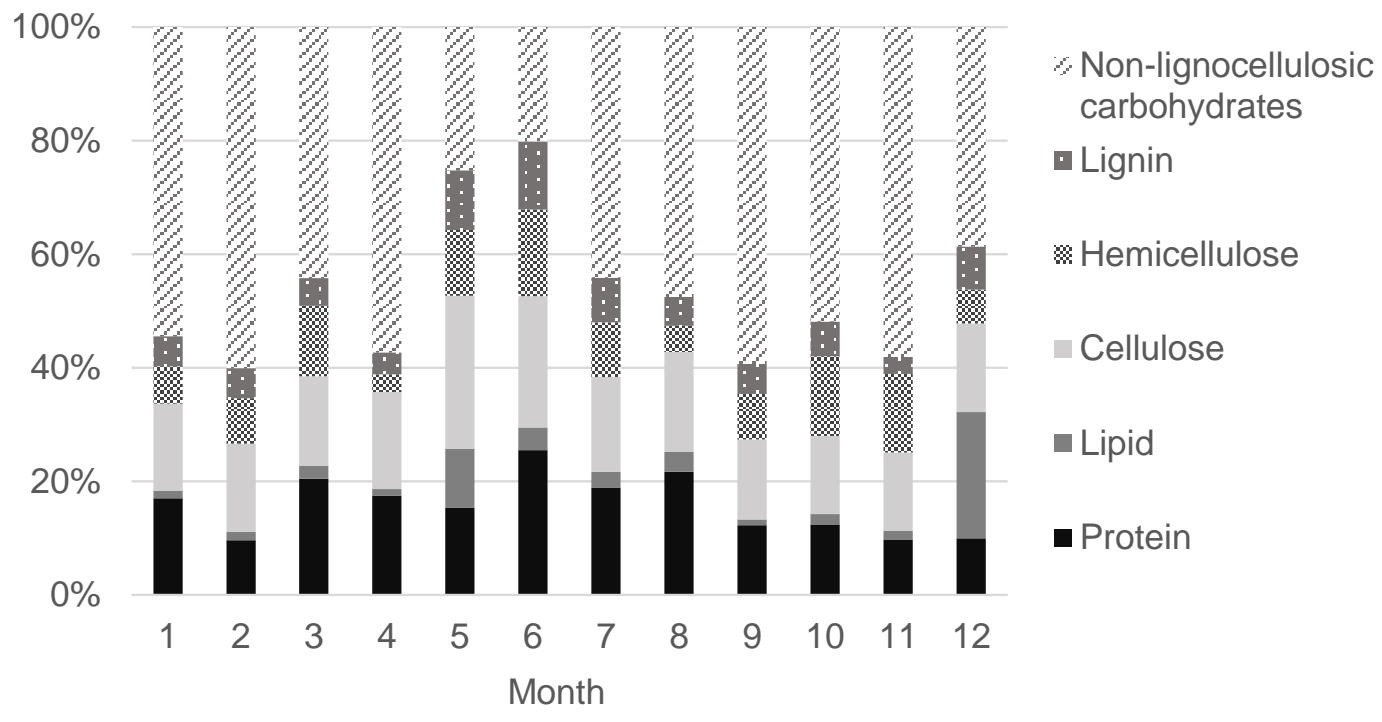

Figure 2 . 
Edwiges, T., Mayer, B., Frare, L., Lins, L., Triolo, J.M., Flotats, X., Sarolli, M., (2017). Influence of chemical composition on biochemical methane potential of fruit and vegetable waste. Waste Management (accepted May 18th). DOI: https://doi.org/10.1016/j.wasman.2017.05.030
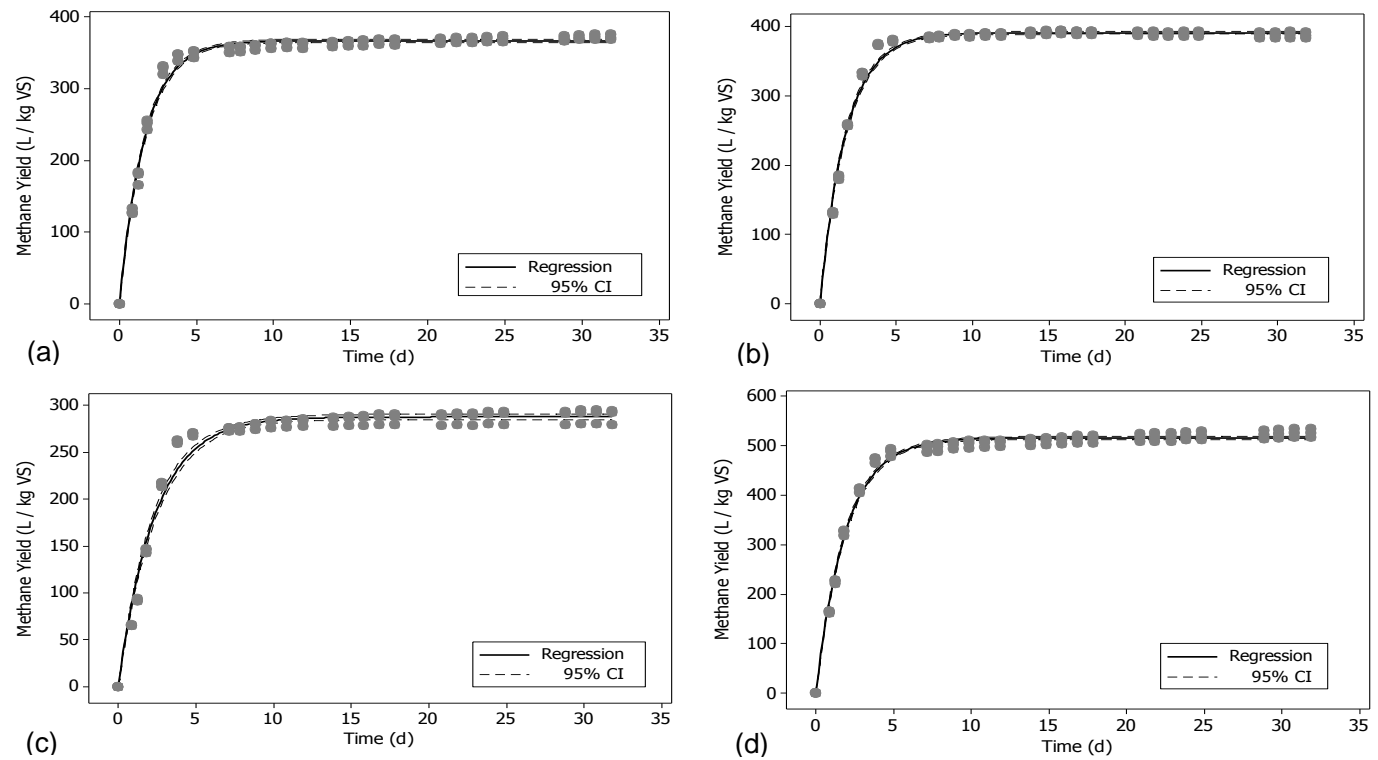

Figure 3. 
Edwiges, T., Mayer, B., Frare, L., Lins, L., Triolo, J.M., Flotats, X., Sarolli, M., (2017). Influence of chemical composition on biochemical methane potential of fruit and vegetable waste. Waste Management (accepted May 18th). DOI: https://doi.org/10.1016/i.wasman.2017.05.030
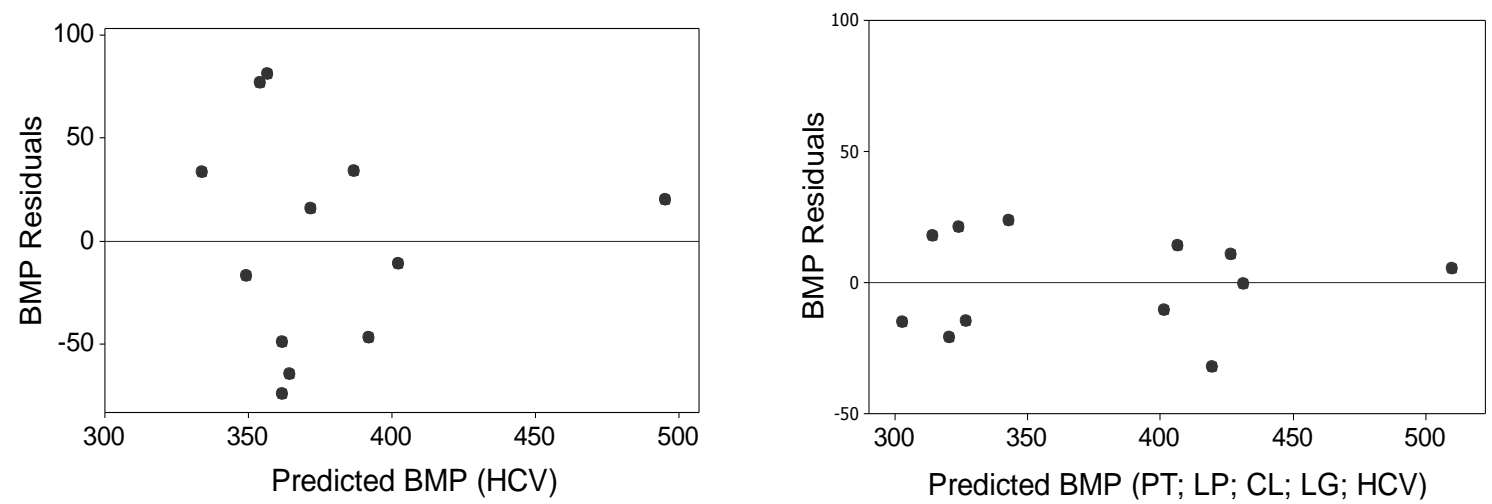

Figure 4. 
Edwiges, T., Mayer, B., Frare, L., Lins, L., Triolo, J.M., Flotats, X., Sarolli, M., (2017). Influence of chemical composition on biochemical methane potential of fruit and vegetable waste. Waste Management (accepted May 18th). DOI: https://doi.org/10.1016/i.wasman.2017.05.030

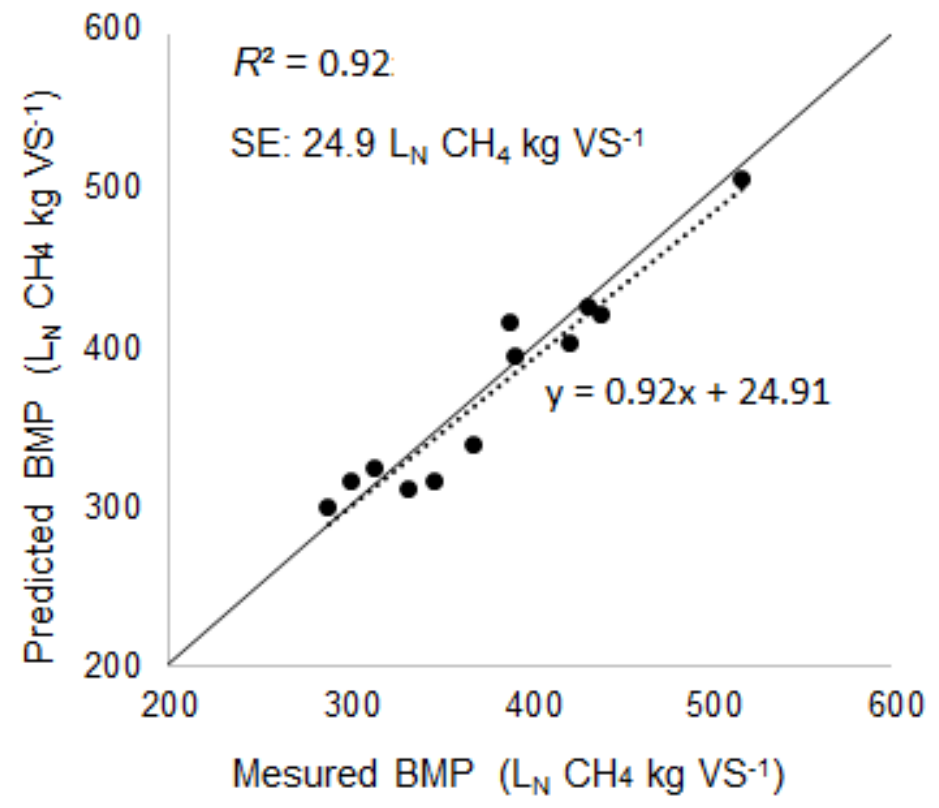

Figure 5. 
Edwiges, T., Mayer, B., Frare, L., Lins, L., Triolo, J.M., Flotats, X., Sarolli, M., (2017). Influence of chemical composition on biochemical methane potential of fruit and vegetable waste. Waste Management (accepted May 18th). DOI: https://doi.org/10.1016/i.wasman.2017.05.030

Table 1 Physical and chemical characteristics of fruit and vegetable waste

\begin{tabular}{|c|c|c|c|c|c|c|c|c|c|c|}
\hline Month & $\mathrm{pH}$ & $\begin{array}{c}\mathrm{HCV} \\
\mathrm{MJ} \mathrm{kg}^{-1 *}\end{array}$ & $\begin{array}{c}\text { TS } \\
\%\end{array}$ & $\begin{array}{l}\mathrm{VS} \\
\% \mathrm{TS}\end{array}$ & $\begin{array}{c}\mathrm{PT} \\
\% \text { VS }\end{array}$ & $\begin{array}{c}\mathrm{LP} \\
\% \mathrm{VS}\end{array}$ & $\begin{array}{c}\text { CL } \\
\% \text { VS }\end{array}$ & $\begin{array}{l}\mathrm{HC} \\
\% \mathrm{VS}\end{array}$ & $\begin{array}{l}\mathrm{LG} \\
\% \mathrm{VS}\end{array}$ & $\begin{array}{l}\text { NLC } \\
\% \text { VS }\end{array}$ \\
\hline Inoculum & 7.5 & 13.5 & 3.2 & 64.9 & 17.4 & 1.2 & 12.8 & 8.6 & 9.6 & 44.1 \\
\hline Jan & 4.3 & 14.8 & 9.2 & 91.3 & 17.0 & 1.4 & 15.3 & 6.6 & 5.3 & 54.4 \\
\hline $\mathrm{Feb}$ & 4.2 & 15.9 & 11.9 & 93.3 & 9.6 & 1.5 & 15.5 & 8.0 & 5.3 & 60.1 \\
\hline Mar & 4.3 & 16.3 & 8.1 & 89.9 & 20.5 & 2.3 & 15.7 & 12.4 & 4.9 & 44.2 \\
\hline Abr & 4.2 & 15.7 & 7.9 & 90.3 & 17.5 & 1.2 & 17.1 & 3.1 & 3.9 & 57.3 \\
\hline May & 4.1 & 17.5 & 9.5 & 92.7 & 15.3 & 10.4 & 26.9 & 11.6 & 10.5 & 25.3 \\
\hline Jun & 4.1 & 17.1 & 8.2 & 92.3 & 25.5 & 4.0 & 23.1 & 15.3 & 12.0 & 20.1 \\
\hline Jul & 4.5 & 16.0 & 9.7 & 93.3 & 18.9 & 2.8 & 16.7 & 9.6 & 7.9 & 44.1 \\
\hline Aug & 3.9 & 15.6 & 7.2 & 90.2 & 21.7 & 3.5 & 17.6 & 4.6 & 5.1 & 47.5 \\
\hline Sep & 4.2 & 15.4 & 7.6 & 92.6 & 12.3 & 1.0 & 14.1 & 8.0 & 5.3 & 59.3 \\
\hline Oct & 4.3 & 15.9 & 8.7 & 91.1 & 12.4 & 1.8 & 13.8 & 14.0 & 6.1 & 51.9 \\
\hline Nov & 4.0 & 16.9 & 13.8 & 93.4 & 9.8 & 1.5 & 13.8 & 13.8 & 3.0 & 58.1 \\
\hline Dec & 4.0 & 21.2 & 11.6 & 93.1 & 9.9 & 22.3 & 15.6 & 6.0 & 7.6 & 38.6 \\
\hline MIN & 3.9 & 14.8 & 7.2 & 89.9 & 9.6 & 1.0 & 13.8 & 3.1 & 3.0 & 20.1 \\
\hline MAX & 4.5 & 21.2 & 13.8 & 93.4 & 25.5 & 22.3 & 26.9 & 15.3 & 12.0 & 60.1 \\
\hline MEAN & 4.2 & 16.5 & 9.5 & 92.0 & 15.9 & 4.5 & 17.1 & 9.4 & 6.4 & 46.7 \\
\hline SD & 0.2 & 1.7 & 2.0 & 1.3 & 5.2 & 6.2 & 4.0 & 4.0 & 2.7 & 13.2 \\
\hline $\mathrm{CV}(\%)$ & 4 & 10 & 21 & 1 & 33 & 138 & 23 & 42 & 41 & 28 \\
\hline
\end{tabular}

$* \mathrm{MJ} \mathrm{kg} \mathrm{material}{ }^{-1}$ dried at $60^{\circ} \mathrm{C}$.

HCV: high calorific value; TS: total solids; VS: volatile solids; PT: protein; LP: lipid; CL: cellulose; HC: hemicellulose; LG: lignin; NLC: non-lignocellulosic carbohydrates; SD: standard deviation; $\mathrm{CV}$ : coefficient of variation. 
Edwiges, T., Mayer, B., Frare, L., Lins, L., Triolo, J.M., Flotats, X., Sarolli, M., (2017). Influence of chemical composition on biochemical methane potential of fruit and vegetable waste. Waste Management (accepted May 18th). DOI: https://doi.org/10.1016/i.wasman.2017.05.030

Table 2 Results from batch tests and theoretical production

\begin{tabular}{|c|c|c|c|c|c|c|c|c|}
\hline Month & ISR & $\begin{array}{c}\mathrm{pH} \\
\text { Start - End }\end{array}$ & $\begin{array}{c}\text { BMP } \\
{\text { [C.I. } 95 \%]^{1}}_{\text {Ln kgvs }^{-1}}^{1}\end{array}$ & $\begin{array}{c}\text { Methane } \\
\text { Content } \\
(\%)\end{array}$ & $\begin{array}{c}K_{d i s} \\
\text { [C.I. 95\%] }\end{array}$ & $\begin{array}{c}\text { MPR } \\
{[\text { C.I. } 95 \%]} \\
\mathrm{LN}_{\mathrm{NgVs}}{ }^{-1} \mathrm{~d}^{-1}\end{array}$ & $\begin{array}{c}\text { TBMP } \\
\text { L }_{N} k_{v S^{-1}}{ }^{-1}\end{array}$ & $\begin{array}{l}\mathrm{BD} \\
(\%)\end{array}$ \\
\hline Jan & 4.1 & $7.3-7.7$ & $367 \pm 2^{E}$ & $72 \pm 0.2$ & $0.61 \pm 0.02$ & $224 \pm 0.05$ & 454 & 81 \\
\hline Feb & 3.8 & $7.3-7.7$ & $312 \pm 3^{\mathrm{H}}$ & $68 \pm 2.2$ & $0.56 \pm 0.03$ & $175 \pm 0.08$ & 448 & 70 \\
\hline Mar & 4.0 & $7.3-7.8$ & $387 \pm 3^{\mathrm{D}}$ & $62 \pm 5.5$ & $0.64 \pm 0.03$ & $248 \pm 0.09$ & 461 & 84 \\
\hline Apr & 3.6 & $7.3-7.1$ & $438 \pm 5^{\text {B }}$ & $76 \pm 1.9$ & $0.39 \pm 0.03$ & $171 \pm 0.15$ & 448 & 98 \\
\hline May & 3.3 & $7.2-7.9$ & $391 \pm 2^{D}$ & $58 \pm 2.4$ & $0.59 \pm 0.03$ & $231 \pm 0.07$ & 523 & 75 \\
\hline Jun & 3.7 & $7.4-7.9$ & $345 \pm 3^{F}$ & $61 \pm 0.1$ & $0.66 \pm 0.04$ & $228 \pm 0.12$ & 497 & 69 \\
\hline Jul & 3.2 & $7.2-7.7$ & $300 \pm 8^{I}$ & $70 \pm 6.0$ & $0.42 \pm 0.06$ & $126 \pm 0.46$ & 472 & 64 \\
\hline Aug & 3.2 & $7.2-7.7$ & $431 \pm 3^{\mathrm{BC}}$ & $73 \pm 0.2$ & $0.46 \pm 0.02$ & $198 \pm 0.07$ & 470 & 92 \\
\hline Sep & 3.1 & $7.3-7.8$ & $332 \pm 4^{\mathrm{G}}$ & $65 \pm 2.7$ & $0.38 \pm 0.02$ & $126 \pm 0.09$ & 448 & 74 \\
\hline Oct & 3.2 & $7.2-7.7$ & $288 \pm 3^{\mathrm{J}}$ & $61 \pm 1.1$ & $0.43 \pm 0.02$ & $124 \pm 0.06$ & 455 & 63 \\
\hline Nov & 3.2 & $7.2-7.8$ & $421 \pm 3^{C}$ & $71 \pm 0.8$ & $0.51 \pm 0.02$ & $215 \pm 0.05$ & 441 & 95 \\
\hline Dec & 3.2 & $7.1-7.8$ & $516 \pm 3^{A}$ & $71 \pm 1.3$ & $0.52 \pm 0.01$ & $268 \pm 0.03$ & 580 & 89 \\
\hline MIN & 3.1 & $7.2-7.1$ & 288 & 58 & 0.38 & 124 & 441 & 63 \\
\hline MAX & 4.1 & $7.4-7.9$ & 516 & 76 & 0.66 & 268 & 580 & 98 \\
\hline MEAN & 3.5 & $7.3-7.7$ & 377 & 68 & 0.51 & 194 & 475 & 79 \\
\hline SD & 0.4 & $0.1-0.2$ & 67 & 6 & 0.1 & 50 & 41 & 12 \\
\hline $\mathrm{CV}(\%)$ & 10 & $1-2$ & 18 & 8 & 19 & 26 & 9 & 15 \\
\hline
\end{tabular}

${ }^{1}$ Different letters indicate significant differences with $\alpha<0.05$, following variance analysis. ISR: inoculum to substrate ratio; BMP: biochemical methane potential; C.I.: confidence interval; $K_{d i s}$ : constant of disintegration; MPR: methane production rate; TBMP: theoretical biochemical methane potential; BD: biodegradability (BMP/TBMP)*100. 
Edwiges, T., Mayer, B., Frare, L., Lins, L., Triolo, J.M., Flotats, X., Sarolli, M., (2017). Influence of chemical composition on biochemical methane potential of fruit and vegetable waste. Waste Management (accepted May 18th). DOI: https://doi.org/10.1016/i.wasman.2017.05.030

Table 3 Pearson correlation matrix between variables

\begin{tabular}{cccccccccc}
\hline & HCV & PT & LP & CL & HC & LG & NLC & BMP & $K_{\text {dis }}$ \\
\hline PT & -0.26 & & & & & & & \\
LP & 0.92 & -0.24 & & & & & & & \\
CL & 0.26 & 0.47 & 0.26 & & & & & \\
HC & 0.14 & 0.09 & -0.14 & 0.21 & & & & \\
LG & 0.42 & 0.41 & 0.41 & 0.80 & 0.39 & & & \\
NLC & -0.53 & -0.53 & -0.49 & -0.83 & -0.41 & -0.91 & & & \\
\hline BMP & 0.59 & -0.08 & 0.64 & 0.06 & -0.44 & -0.15 & -0.12 & & \\
Kdis & 0.24 & 0.31 & 0.17 & 0.44 & 0.43 & 0.42 & -0.55 & 0.07 & \\
MPR & 0.59 & 0.14 & 0.57 & 0.34 & 0.05 & 0.21 & -0.48 & 0.69 & 0.76 \\
\hline
\end{tabular}

*Coefficients with $p<0.05$ are highlighted.

$R<|0.40|$ weak correlation; $R|0.40|-|0.70|$ moderate correlation; $\mathrm{R}>|0.70|$ strong correlation. 
Edwiges, T., Mayer, B., Frare, L., Lins, L., Triolo, J.M., Flotats, X., Sarolli, M., (2017). Influence of chemical composition on biochemical methane potential of fruit and vegetable waste. Waste Management (accepted May 18th). DOI: https://doi.org/10.1016/i.wasman.2017.05.030

Table 4 Summary regression models to predict biochemical methane potential (BMP)

\begin{tabular}{|c|c|c|c|c|c|}
\hline Model & $\begin{array}{l}\mathbf{N}^{\circ} \\
\text { Var. }\end{array}$ & Variable & Equation & SE & $\mathbf{R}^{2}$ \\
\hline 1 & 1 & $\mathrm{HCV}$ & $\mathrm{BMP}=-40+25.3 \mathrm{HCV}$ & 54.8 & 0.391 \\
\hline 2 & 1 & LP & $\mathrm{BMP}=346+6.96 \mathrm{LP}$ & 53.8 & 0.411 \\
\hline 3 & 1 & LG & $\mathrm{BMP}=402-3.85 \mathrm{LG}$ & 69.3 & 0.023 \\
\hline 4 & 2 & LP, LG & $\mathrm{BMP}=418+9.24 \mathrm{LP}-12.8 \mathrm{LG}$ & 45.4 & 0.623 \\
\hline 5 & 3 & $\begin{array}{l}\text { LP, LG } \\
\text { NLC }\end{array}$ & $\mathrm{BMP}=845+7.59 \mathrm{LP}-36.9 \mathrm{LG}-5.67 \mathrm{NLC}$ & 34.3 & 0.809 \\
\hline 6 & 4 & $\begin{array}{l}\text { PT, LP, } \\
\text { CL, LG }\end{array}$ & $\mathrm{BMP}=279+5.47 \mathrm{PT}+12.0 \mathrm{LP}+8.99 \mathrm{CL}-30.5 \mathrm{LG}$ & 27.6 & 0.891 \\
\hline 7 & 5 & $\begin{array}{c}\text { PT, LP, CL, } \\
\text { LG, HCV }\end{array}$ & $\mathrm{BMP}=-73+5.85 \mathrm{PT}+6.62 \mathrm{LP}+9.91 \mathrm{CL}-32.0 \mathrm{LG}+22.0 \mathrm{HCV}$ & 24.9 & 0.925 \\
\hline
\end{tabular}

No Var.: number of variables used in the model; HCV: high calorific value; LP: lipid; LG: lignin; NLC: non-lignocellulosic carbohydrate; PT: protein; CL: cellulose; BMP is expressed in $\mathrm{L}_{\mathrm{N}} \mathrm{CH}_{4} \mathrm{~kg} \mathrm{VS}^{-1}$; coefficient of chemical components is expressed in \% VS; coefficient of $\mathrm{HCV}$ is expressed in $\mathrm{MJ} \mathrm{kg}^{-1}$. SE indicates standard error of the regression. 